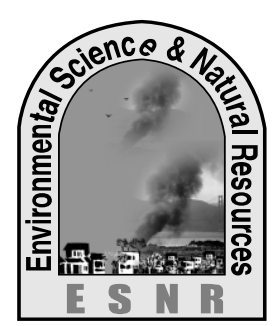

\title{
Preparation and Sensorial Evaluation of Pickles, Jam, Jelly and Squash Developed from Jackfruit (Artocarpus heterophyllus)
}

\author{
C. Mondal*, S. Sultana, M. A. Mannan and S. A. K. U. Khan
}

Agrotechnology Discipline, Khulna University, Khulna-9208, Bangladesh

*Corresponding author: chhoa_at07@yahoo.com

\begin{abstract}
The investigation was conducted in the Molecular Horticulture Laboratory of Agrotechnology Discipline, Khulna University to develop processed products from jackfruit through their sensory evaluation in order to see their suitability and consumer acceptability. Using variation in sugar contents five preparations of raw jackfruit green pickle, four preparations of rind jelly and bulb jelly, and three preparations of jam, squash and sweet pickles were successfully prepared. Results from sensory evaluation using a seven point hedonic scale to rate for color, taste, flavor, texture and overall acceptability by untrained panelists indicated preparation No. 3 of green pickle, preparation No. 3 and 4 of rind jelly, preparation No. 2 of bulb jelly, jam, squash and sweet pickle scored highest among all the preparations. The storage of these products in normal room temperature showed that produced pickles remain unchanged even after 12 months of storage. But the quality of jam, jelly and squash started to deteriorate after 7 months of storage due to the absence of preservatives. Based on results, it can be concluded that commercial production of the products by using different parts of jackfruit can be taken up and promoted as a small scale income generating activity.
\end{abstract}

Key words: Acceptability, Jelly, Pickle, Processed products and Sensory evaluation

\section{Introduction}

Jackfruit (Artocarpus hetrophyllus) is the largest edible fruit in the world and it is the national fruit of Bangladesh. The poor people of Jackfruit growing area, used to eat this fruit instead of rice, for one of their daily meals. Hence, Jackfruit is called "poor man's food". People consumed it mostly as a fruit when ripe but also as vegetable in the unripe stage. The Jackfruit significantly contributes to the nutrition of the people of this country as a source of vitamins, minerals and calories. Both tender and ripe fruits as well as the seeds are rich in minerals and vitamins. At present (BBS, 2015) Bangladesh produces 1169304 tons of Jackfruit annually from an area of 9031 hectares of land at the rate of 129 tons per hectare. It ranks second in annual production among the fruits grown in Bangladesh (BBS, 2015).

The fruit pulp is sweet and tasty and used as dessert or preserved in syrup. The seeds contained in the ripe fruits are also cooked. The fruits and seeds are also processed in a variety of ways for food and other products. It is a good source of carotene (vit-A) and ascorbic acid with moderate amount of minerals. Jackfruits have more protein, calcium, thiamine, riboflavin and carotene than banana but less nutrition than mango (Hossain et al., 1979).

However, the fruit is perishable and cannot be stored for long time because of its inherent compositional and textural characteristics. In every year, a considerable amount of Jackfruit, specially obtained in the glut season (June-July) goes waste due to lack of proper postharvest knowledge during harvesting, transporting and storing both in quality and quantity. Proper postharvest technology for prolonging shelf life is, therefore, necessary. Besides, alternate ways of using jackfruits in no-seasons plays significant roles in reducing postharvest losses. Among them, processing is important one. It adds diversified and attractive food items in dietary menu as well as contributes to generation of income and employment.

A number of products have been developed from raw, tender and ripe fruits and seeds. The ripe fruits bulbs (excluding seed) and the rind of the fruit (including perianth and unfertilized flowers) have been used for processing in number of products. Ripe jackfruit bulbs are canned in syrup, made into jams either pure or mixed with dehydrated bulbs, chutney, preserves, candy, and concentrate and powder. Rinds of ripe fruit are made into jelly. Preservation of fruits by processing has been the research pursuits of many developed and developing countries and has yielded quite a number of technologies. Home and cottage level processing of some fruits, specially 'Berry, Tamarind, Indian olive,' etc. exists in Bangladesh. However, processing techniques of jackfruit is very scanty in Bangladesh. There has been a little research worth mentioning to find possibility of processing of jackfruit into durable and nutritious food products. So, it is now a burning issue to reduce to losses by developing processing technique of jackfruit. Cottage industries establishment can be encouraged in our country, efforts of which are yet quite inadequate. In consideration of the above circumstance, the present study was under taken to develop products by processing different parts of jackfruits and evaluate the quality attribute by using sensory evaluation.

\section{Materials and Methods}

Collection and preparation of experimental materials The experimental materials, fully matured and disease free jackfruit were collected from the South Western 
region of Bangladesh viz. Khulna, Jessore, and some from the germplasm center of the Agrotechnology Discipline, Khulna University, Khulna during June 2010 to May 2011. After collecting they were transported to the molecular horticulture lab, Agrotechnology Discipline, Khulna University by using temperature controlled vehicle then the green, welldeveloped, tender seeded fresh jackfruits were selected. The fruits were collected carefully to avoid the latextouch to the rind.

\section{Experimental design and method of analysis}

The experiments were laid out in completely randomized design (CRD) with three replications and 3 to 5 formulations. Sensory evaluation of jackfruit products were done following the technique adopted by Hossain and Siddique (1982).

\section{Products developed from jackfruit}

\section{Green jackfruit pickle}

Green jackfruit pickle formulation was prepared by following the process described by Tilak (1995) with some modifications as using only variation in sugar content in five formulations (Table 1).

\section{Jackfruit rind jelly}

Four formulations of jackfruit rind jelly were prepared according to the process described by Tilak (1995) maintaining variation in sugar content (Table 1).

\section{Jackfruit bulb jelly}

The formulations were prepared by following the process described by Razzaque (2007) and its modifications (Table 1).

\section{Jackfruit jam}

Among the formulations of jackfruit jam 3 were prepared according to the formulation described by Tilak (1995), variation in sugar content was maintained in other formulations (Table 1).

\section{Jackfruit squash}

The process described by Razzaque (2007) and its modification were followed to prepare the formulations for jackfruit squash. Variation in sugar content was maintained in the modified formulations (Table 1).

\section{Jackfruit sweet pickle}

The process described by Tilak (1995) and its modification were followed to prepare the formulations for jackfruit sweet pickle. Variation in sugar content was maintained in the modified formulations (Table 1).

\section{Sensory Evaluation}

The acceptability of the prepared products was evaluated through a taste-testing panel of 20 judges. All the judges were conversant with the factors governing the quality of the products. The processed products were served to each judge who independently examined the products quality and assigned score for the characteristics- i) color ii) taste iii) flavor iv) texture and v) over all acceptability of individual products. The panelists recorded their preferential comments in the supplied questionnaire. The results have been presented both in percentage figures and in acceptability scores. Acceptability score was computed according to the scale as followed by Hossain and Siddique (1982). The scale provided scores of 7, 5, and 2 for the preferential comments "highly acceptable", "slightly acceptable" and "unacceptable" respectively. All the treatments of each product were evaluated on the basis of the scores given by the panelists.

\section{Storage Study}

All the prepared samples were stored at room temperature for a period of 12 months. The stored samples were examined monthly. The colour, taste, flavor, texture and overall acceptability were examined during the storage period for about 12 months.

\section{Data Analysis}

The collected data were statistically analyzed by Analysis of Variance method. Least Significant Difference (LSD) was used to compare the means of different parameters. 
Table 1. Formulations of different preparations

\begin{tabular}{|c|c|c|c|c|c|c|}
\hline Ingredients & Green pickle & $\begin{array}{l}\text { Sweet } \\
\text { pickle }\end{array}$ & Rind jelly & $\begin{array}{l}\text { Bulb } \\
\text { jelly }\end{array}$ & Jam & Squash \\
\hline Jackfruit (g) & 500 & 500 & - & - & - & - \\
\hline Jackfruit juice (ml) & - & - & 500 & 450 & - & 250 \\
\hline Jackfruit pulp (ml) & - & - & - & - & 450 & - \\
\hline Mustard oil (ml) & 125 & 100 & - & - & - & - \\
\hline Sugar $(g)$ & $\begin{array}{l}\mathrm{T}_{1}=27.5, \mathrm{~T}_{2}=30, \\
\mathrm{~T}_{3}=37, \quad \mathrm{~T}_{4}=40, \\
\mathrm{~T}_{5}=42.5\end{array}$ & $\begin{array}{l}\mathrm{T}_{1}=80 \\
\mathrm{~T}_{2}=60 \\
\mathrm{~T}_{3}=40\end{array}$ & $\begin{array}{l}\mathrm{T}_{1}=300 \\
\mathrm{~T}_{2}=350 \\
\mathrm{~T}_{3}=200 \\
\mathrm{~T}_{4}=250\end{array}$ & $\begin{array}{l}\mathrm{T}_{1}=150 \\
\mathrm{~T}_{2}=120 \\
\mathrm{~T}_{3}=50 \\
\mathrm{~T}_{4}=45\end{array}$ & $\begin{array}{l}\mathrm{T}_{1}=225 \\
\mathrm{~T}_{2}=200 \\
\mathrm{~T}_{3}=150\end{array}$ & $\begin{array}{l}\mathrm{T}_{1}=340, \\
\mathrm{~T}_{2}=360 \\
\mathrm{~T}_{3}=380\end{array}$ \\
\hline Zinger $(\mathrm{g})$ & 10 & 9 & - & - & - & - \\
\hline Mustard powder (g) & 5.6 & 5.6 & - & - & - & - \\
\hline Pepper $(\mathrm{g})$ & 3.6 & - & - & - & - & - \\
\hline Dried peeper (piece) & 3 & - & - & - & - & - \\
\hline Turmeric $(\mathrm{g})$ & 2.5 & 2.5 & - & - & - & - \\
\hline Cumin (g) & 1.5 & 1.5 & - & - & - & - \\
\hline Aniseed (g) & 1.5 & 1.5 & - & - & - & - \\
\hline Fenugreek $(\mathrm{g})$ & 2 & 1.7 & - & - & - & - \\
\hline Black cumin $(\mathrm{g})$ & 1 & 1.5 & - & - & - & - \\
\hline Cinnamon $(\mathrm{g})$ & 1.5 & 1.5 & - & - & - & - \\
\hline Cardamom (piece) & 1 & 1 & - & - & - & - \\
\hline Salt $(g)$ & 50 & - & - & - & - & - \\
\hline Vinegar (ml) & 100 & 100 & - & - & - & - \\
\hline Bay leaf (piece) & 2 & - & - & - & - & - \\
\hline Clove (piece) & 4 & 4 & - & - & - & - \\
\hline Citric acid (g) & - & - & - & 1.5 & 2.5 & 10 \\
\hline Pectin $(\mathrm{g})$ & - & - & 10 & 5 & 5 & - \\
\hline Agar $(g)$ & - & - & 2 & 1 & - & - \\
\hline KMS (g) & - & - & 0.7 & 0.3 & - & 0.6 \\
\hline Lemon (piece) & - & - & 1 & Half & Half & 1 \\
\hline Water $(\mathrm{ml})$ & - & - & - & 450 & - & 385 \\
\hline Sodium benzoate & - & - & - & - & 1.2 & - \\
\hline
\end{tabular}

\section{Results and Discussion}

\section{Sensory evaluation of processed products}

\section{Green jackfruit pickle}

Immediately after preparation the processed green jackfruit pickles were evaluated organoleptically. The preferential comments of expert panel members on color, taste, flavor and texture have been presented below:

\section{Color, Taste, Flavor and Texture}

In respect of overall consideration of color, taste, flavor and texture of green pickle preparation No. 3 (37g sugar) showed better performance among the 5 preparations. This preparation showed maximum organoleptic score (7.00) for most of the preparations under study as color, taste and flavor. However the finest texture (6.20) was obtained from the preparation No. 4 and 5 (Table 2)

Table 2. Organoleptic Test of Green Pickle

\begin{tabular}{|c|c|c|c|c|c|}
\hline No. of preparation & Color & Taste & Flavor & Texture & Overall acceptability \\
\hline $\mathrm{T}_{1}$ & $4.20 \mathrm{c}$ & $4.20 \mathrm{c}$ & $4.20 \mathrm{c}$ & $3.20 \mathrm{~b}$ & $17.80 \mathrm{~b}$ \\
\hline $\mathrm{T}_{2}$ & $5.00 \mathrm{bc}$ & $5.00 \mathrm{bc}$ & $5.40 \mathrm{bc}$ & $2.60 \mathrm{~b}$ & $18.80 \mathrm{~b}$ \\
\hline $\mathrm{T}_{3}$ & $7.00 \mathrm{a}$ & $7.00 \mathrm{a}$ & $7.00 \mathrm{a}$ & $5.80 \mathrm{a}$ & $26.40 \mathrm{a}$ \\
\hline $\mathrm{T}_{4}$ & $6.60 \mathrm{a}$ & $6.60 \mathrm{a}$ & $7.00 \mathrm{a}$ & $6.20 \mathrm{a}$ & $25.60 \mathrm{a}$ \\
\hline $\mathrm{T}_{5}$ & $5.80 \mathrm{ab}$ & $5.80 \mathrm{ab}$ & $6.60 \mathrm{ab}$ & $6.20 \mathrm{a}$ & $25.60 \mathrm{a}$ \\
\hline Level of significance & $* *$ & $* *$ & $* *$ & $* *$ & $* *$ \\
\hline
\end{tabular}

** = Significant at $1 \%$ level

Color, Taste, Flavor and Texture of sweet pickle 
The maximum organoleptic score of color (6.60), taste (6.20), flavor (6.60) and texture (6.20) of sweet pickle was obtained in preparation No. 2 (60g sugar). Better performance among all the 3 preparations as overall acceptability was also found in preparation No.2 (Table 3)

Table 3. Organoleptic Test of Sweet pickle

\begin{tabular}{|c|c|c|c|c|c|}
\hline No. of treatment & Color & Taste & Flavor & Texture & Overall acceptability \\
\hline $\mathrm{T}_{1}$ & $4.20 \mathrm{~b}$ & $3.80 \mathrm{~b}$ & $4.40 \mathrm{~b}$ & $3.80 \mathrm{~b}$ & $16.20 \mathrm{~b}$ \\
\hline $\mathrm{T}_{2}$ & $6.60 \mathrm{a}$ & $6.20 \mathrm{a}$ & $6.60 \mathrm{a}$ & $6.20 \mathrm{a}$ & $25.60 \mathrm{a}$ \\
\hline $\mathrm{T}_{3}$ & $3.80 \mathrm{~b}$ & $3.80 \mathrm{~b}$ & $3.20 \mathrm{~b}$ & $2.60 \mathrm{~b}$ & $14.00 \mathrm{~b}$ \\
\hline $\begin{array}{c}\text { Level of } \\
\text { significance }\end{array}$ & $* *$ & $* *$ & $* *$ & $* *$ & $* *$ \\
$* *$ & & & & \\
\hline
\end{tabular}

Preparation No. 3 of green pickle and preparation No. 2 of sweet pickle were acceptable even after 12 months of storage. The results were agreed with the experiment of Divakar et al. (2012) who showed that after sensory evaluation jackfruit pith pickle was acceptable even at the end of 6 months of storage. Sweet peach pickle prepared with 5.50 per cent salt and $60^{\circ} \mathrm{B}$ TSS of syrup obtained best scores for the organoleptic quality parameters like color (7.30), flavor (7.50), texture (7.40) and overall acceptability (7.50) (Attri and Sharma, 2016) similar results obtained by Bhuiyan (2012) in case of hog plum pickle. Hosain et al. (2010) indicated that among three samples of okra pickle, the pickle which was processed in sugar and oil mixed was the most acceptable. The sample in which bitter gourd and bottle gourd was in the ratio 60:40 was the most acceptable sample of pickle (Pingale et al., 2015).

But Yusof and Vengrasalam (1994) found no significant difference in flavor, taste among the four samples of carambola pickles.

\section{Color, Taste, Flavor and Texture of rind jelly}

In respect of overall preparation No. 3 and 4 showed similar performance. The preparation No. 3 obtained maximum organoleptic score of color (5.00) and taste (4.40) whereas the preparation No.4 attained maximum organoleptic score of flavor (5.00) and texture (5.00) for most of the preparations under study (Table 4).

Table 4. Organoleptic Test of Rind jelly

\begin{tabular}{|c|c|c|c|c|c|}
\hline \multirow{2}{*}{ No. of treatment } & Color & Taste & Flavor & Texture & Overall acceptability \\
\hline $\mathrm{T}_{1}$ & $2.00 \mathrm{c}$ & $2.00 \mathrm{~b}$ & $2.00 \mathrm{~b}$ & $2.00 \mathrm{~b}$ & $8.00 \mathrm{~b}$ \\
\hline $\mathrm{T}_{2}$ & $2.00 \mathrm{c}$ & $2.00 \mathrm{~b}$ & $2.00 \mathrm{~b}$ & $2.00 \mathrm{~b}$ & $8.00 \mathrm{~b}$ \\
\hline $\mathrm{T}_{3}$ & $5.00 \mathrm{a}$ & $4.40 \mathrm{a}$ & $4.40 \mathrm{a}$ & $2.60 \mathrm{~b}$ & $16.40 \mathrm{a}$ \\
\hline $\mathrm{T}_{4}$ & $3.20 \mathrm{~b}$ & $3.20 \mathrm{ab}$ & $5.00 \mathrm{a}$ & $5.00 \mathrm{a}$ & $16.40 \mathrm{a}$ \\
\hline $\begin{array}{c}\text { Level of } \\
\text { significance }\end{array}$ & $* *$ & $* *$ & $* *$ & $* *$ & $* *$ \\
\hline
\end{tabular}

$* *=$ Significant at $1 \%$ level

\section{Color, Taste, Flavor and Texture of bulb jelly}

In respect of overall acceptability preparation No. 2 (120g sugar) showed best performance (26.40) among all the preparations. The maximum organoleptic score of color, taste, flavor and texture (6.60) was found in preparation No. 2 (120g sugar) (Table 5). The result is similar with the result of Islam et al. (2012) who experimented that dragon fruit jelly containing $1.5 \%$ pectin secured the highest score for color, flavor, turbidity and overall acceptability. Similar results obtained by da Silva Junior et al. (2013) in case of cactus-pear jelly and Kesava Reddy et al. (2016). Singh and Chandra (2012) concluded that fruit jelly prepared with guava extract and carrot juice ratio of 75:25 was superior. On the contrary, this result differs from the study of Fernandes et al. (2014), observed no significant differences in the appearance, taste, sweetness, acidity and global assessment but significant differences on color among 7 grape jellies. 
Table 5. Organoleptic Test of Bulb jelly

\begin{tabular}{|c|c|c|c|c|c|}
\hline No. of treatment & Color & Taste & Flavor & Texture & $\begin{array}{c}\text { Overall } \\
\text { acceptability }\end{array}$ \\
\hline $\mathrm{T}_{1}$ & $3.20 \mathrm{~b}$ & $3.80 \mathrm{~b}$ & $3.80 \mathrm{~b}$ & $3.20 \mathrm{~b}$ & $14.00 \mathrm{~b}$ \\
\hline $\mathrm{T}_{2}$ & $6.60 \mathrm{a}$ & $6.60 \mathrm{a}$ & $6.60 \mathrm{a}$ & $6.60 \mathrm{a}$ & $26.40 \mathrm{a}$ \\
\hline $\mathrm{T}_{3}$ & $3.80 \mathrm{~b}$ & $3.80 \mathrm{~b}$ & $4.40 \mathrm{~b}$ & $2.60 \mathrm{~b}$ & $14.60 \mathrm{~b}$ \\
\hline $\mathrm{T}_{4}$ & $3.20 \mathrm{~b}$ & $3.20 \mathrm{~b}$ & $3.80 \mathrm{~b}$ & $3.80 \mathrm{~b}$ & $14.00 \mathrm{~b}$ \\
\hline Level of significance & $* *$ & $* *$ & $* *$ & $* *$ & $* *$ \\
\hline
\end{tabular}

$* *=$ Significant at $1 \%$ level

\section{Color, Taste, Flavor and Texture of jam}

The preparation No. 2 obtained maximum organoleptic score for most of the preparations under study as color (6.60), taste (7.00), flavor (7.00), texture (7.00) and overall consideration (Table 6).

The jam containing $200 \mathrm{~g}$ sugar was mostly accepted by the panelist; the findings are in agreement with the findings of Kushala et al. (2012) who reported that appearance, aroma and flavor of blended jackfruit jam was influenced by high levels of pulp and sugars interaction. Reddy (2004) and Bhatnagar (1991) observed similar results in aonla jam watermelon rind jam respectively. Singh and Kumar (1995) reported that aonla jam prepared with 45 per cent pulp, 68 per cent TSS and 1 per cent acidity got highest organoleptic score. Eke-Ejiofor and Owuno (2013) successfully used sensory attributes for the preparation of jam to add value to the fruit, reduce post harvest losses. Good jam has a soft even consistency without distinct pieces of fruit, a bright color, a good fruit flavor and a semijellied texture that is easy to spread but has no free liquid (Berolzheimer et al., 1959).

Patil et al. (2013) showed among the blended jams, the highest score was judged in the treatment $60 \%$ guava pulp and 40\% sapota pulp. Ihediohanma et al. (2014) observed significant difference in color and aroma of the samples of jackfruit, pineapple and orange jam while there was no significant difference in the texture and sweetness of samples tested.

Table 6. Organoleptic Test of jam

\begin{tabular}{|c|c|c|c|c|c|}
\hline No. of treatment & Color & Taste & Flavor & Texture & Overall acceptability \\
\hline $\mathrm{T}_{1}$ & $2.60 \mathrm{c}$ & $3.20 \mathrm{~b}$ & $3.20 \mathrm{~b}$ & $2.60 \mathrm{~b}$ & $11.00 \mathrm{c}$ \\
\hline $\mathrm{T}_{2}$ & $6.60 \mathrm{a}$ & $7.00 \mathrm{a}$ & $7.00 \mathrm{a}$ & $7.00 \mathrm{a}$ & $26.80 \mathrm{a}$ \\
\hline $\mathrm{T}_{3}$ & $4.40 \mathrm{~b}$ & $3.80 \mathrm{~b}$ & $3.80 \mathrm{~b}$ & $3.20 \mathrm{~b}$ & $14.60 \mathrm{~b}$ \\
\hline $\begin{array}{c}\text { Level of } \\
\text { significance }\end{array}$ & $* *$ & $* *$ & $* *$ & $* *$ & $* *$ \\
\hline
\end{tabular}

$* *=$ Significant at $1 \%$ level

\section{Color, Taste, Flavor and Texture of Squash}

Maximum organoleptic score as color (7.00), taste (7.00), flavor (6.20), texture (6.20) and overall consideration was found in preparation No. 2 among most of the preparations (Table 7). The squash containing $360 \mathrm{~g}$ sugar were accepted by most of the panelist. Similar results were obtained by Hashmi et al. (2007) who prepared synthetic orange and mango squashes for diabetic patients by using sorbitol instead of sucrose. Jothi et al. (2014) indicated the carrot and papaya juice in same proportion gave the highest consumer acceptability.

Table 7. Organoleptic Test of squash

\begin{tabular}{|c|c|c|c|c|c|}
\hline No. of treatment & Color & Taste & Flavor & Texture & Overall acceptability \\
\hline $\mathrm{T}_{1}$ & $2.60 \mathrm{~b}$ & $2.00 \mathrm{c}$ & $2.00 \mathrm{c}$ & $2.00 \mathrm{c}$ & $8.00 \mathrm{c}$ \\
\hline $\mathrm{T}_{2}$ & $7.00 \mathrm{a}$ & $7.00 \mathrm{a}$ & $6.20 \mathrm{a}$ & $6.20 \mathrm{a}$ & $26.00 \mathrm{a}$ \\
\hline $\mathrm{T}_{3}$ & $3.20 \mathrm{~b}$ & $3.80 \mathrm{~b}$ & $3.80 \mathrm{~b}$ & $3.80 \mathrm{~b}$ & $14.60 \mathrm{~b}$ \\
\hline $\begin{array}{c}\text { Level of } \\
\text { significance }\end{array}$ & $* *$ & $* *$ & $* *$ & $* *$ & $* *$ \\
\hline$*$ Significant at $1 \%$ level & & & & \\
\hline
\end{tabular}
S




\section{Storage study of the processed products}

The processed products were stored in normal room temperature. After 6 month of storage, quality of the products was evaluated organoleptically by a tastetesting panel. It was found that even after six months of storage, quality of the processed products regarding color, taste, flavor and texture were similar to that of freshly processed products. Among the products, the quality of jelly especially the texture, after 8 months of storage started to deteriorate and gradually become watery after 9 months of storage. Islam et al. (2012) showed all parameters of dragon fruit jelly were acceptable up to 4th month of storage, the quality of the products was deteriorated like as off flavor produced and $\mathrm{pH}$ decreased for all the products.

But the quality of squash especially taste and flavor after 7 months of storage started to deteriorate and gradually become spoiled. Jothi et al. (2014) indicated the processed mixed fruit squash were organoleptically acceptable up to 8 weeks of storage at ambient temperature. Some treatments of jam started to deteriorate after 8 months of storage but the best treatment remain unchanged. In the pickles (i.e., green pickle and sweet-pickle) the quality factors remain unchanged even after 12 months of storage. These findings are similar to the reports for peach pickle given by Attri and Sharma (2016). The storage stability was studied by Bhuiyan (2012) for both the products of hog plum and it is seen that chutney (4 month) was lower than storage stability of pickle (5 month). The microbial studies of Divakar et al. (2012) revealed that jackfruit pith pickle product was free from coliforms, Salmonella, S. aureus during the storage period. The product was microbiologically safe and acceptable from the point of sensory properties and can also be marketed even after a storage period of 6 months. Hosain et al. (2010) showed all the pickles of okra became softer with the passing of time. Singh and Chandra (2012) reported there was decrease in most of physicochemical and sensory qualities during the storage. As the products were prepared without using any chemical preservatives, so, probably due to this reason the quality of jellies and jam started to deteriorate after 7 month of storage. And the main reason of deterioration of squash was high moisture and ascorbic acid content.

Therefore, to prolong the shelf-life of the processed products, especially, in case of jelly, jam and squash, chemical preservatives that are not harmful for human health should be use in recommended dose approved by Bangladesh Standard and Testing Institute (Anonymous, 2004 and Anonymous, 2005).

\section{Conclusions}

This study results that jackfruit has a great potential in developing processed products by using different parts in spite of affecting sensory qualities. All the parts of jackfruit have proved to be of value in processing. The rind of the fruit, which was so far discarded or used rarely as cattle feed has thus, proved to be a promising raw material for jelly making. Therefore, the present study is a sign of bright prospect of processing of jackfruit products to minimize postharvest loss. Moreover, processed products can be sold at high price in off-season by adding preservatives in both local and foreign exchange which will enrich our national economy. But further investigation is necessary to study the economic aspects of the products before recommending for commercial production.

\section{References}

Anonymous. 2004. Bangladesh Standard Specification for Pickles (Second Revision). Bangladesh Standard and Testing Institute (BSTI), MAAN Bhaban, 116/A Tejgaon I/A, Dhaka-1208. pp. 1-9.

Anonymous. 2005. Bangladesh Standard Specification for Jams, Jellies and Marmalades (Second Revision). Bangladesh Standard and Testing Institute (BSTI), MAAN Bhaban, 116/A Tejgaon I/A, Dhaka-1208. pp. 1-14.

Attri, S. and Sharma, A. 2016. Standardization of recipes for preparation of sweet pickle from peach, Prunus persica (L) Batsch fruit. International Journal of Farm Sciences, 6(1): 148-155.

BBS. 2015. Yearbook of Agricultural Statistics of Bangladesh. Planning Division, Ministry of Planning, Peoples Republic of Bangladesh, Dhaka. pp. 203-204.

Berolzheimer, R.; Bentley, M. and Flora, R. 1959. The American Woman's Cook Book. Consolidated Book Publishers, Inc, Cornell University Press. pp. 10-22.

Bhatnagar, D. K. 1991. Utilization of watermelon rind for jam making. Indian Food Packer, 45(1): 46-48.

Bhuiyan, M. H. R. 2012. Pickle and Chutney Development from Fresh Hog Plum (Spondias dulcis). J. Environ. Sci. \& Natural Resources, 5(2): $67-72$.

da Silva Junior, J. J.; Cardoso, R. L.; de Oliveira Fonseca, A. A. and Machado. E. S. 2013. Elaboration and sensorial evaluation of jelly and fruit crystallized cactus pear (Opuntia ficus-indica Mill). IDESIA (Chile). 31(3): 59-64.

Divakar, S.; Ukkuru, M.; Krishnaja, U. and Kumari, M. 2012. Shelf-life studies on raw jack-fruit pith pickle. International Journal of Processing and Post Harvest Technology, 3(2): 209-211.

Eke-Ejiofor, J. and Owuno, F. 2013. The physicochemical and sensory properties of jackfruit (artocarpus heterophilus) jam. International Journal of Nutrition and Food Sciences, 2(3): 149152.

Fernandes, L.; Rodrigues, N.; Pereira, J. A. and Ramalhosa, E. 2014. Physico-chemical and sensory characteristics of jellies made from seven grapevine (Vitis vinifera L.) varieties. Acta agriculturae Slovenica, 103(1): 37-48. 
Hashmi, M. S.; Zeb, A.; Riaz, A. and Shah, A. S. 2007. Preparation and Evaluation OF Synthetic Squashes for Diabetic Patients by Using Sorbitol as Sweetener. Sarhad Journal of Agriculture, 23(2): 459-461.

Hosain, M. M.; Jannat, R.; Islaml, M. M. and Sarker, M. K. U. 2010. Processing and Preservation of Okra Pickle. Progress. Agric., 21(1 \& 2): 215-222.

Hossain, M. M and Siddique, M. A. 1982. Taste and Visual Acceptibility of Some Exotic and Local Cultivars of Sweet Potato. Pakistan Journal of Scientific Research, 34(34): 113-119.

Hossain, M. M.; Haque, A. and Hossain, M. 1979. Nutritive value of Jackfruit, Bangladesh J. Agril., 1(2): 9-12.

Ihediohanma, N. C.; Okafor, D. C. and Adeboye, A. S. 2014. Sensory Evaluation of Jam Produced From Jackfruit (Artocarpus heterophyllus). IOSR Journal of Agriculture and Veterinary Science. 7(5): 41-43.

Islam, M. Z.; Khan, M. T. H.; Hoque, M. M. and Rahman, M. M. 2012. Studies on the Processing and Preservation of Dragon Fruit (Hylocereus undatus) Jelly. The Agriculturists, 10(2): 29-35.

Jothi, J. S.; Karmoker, P. and Sarower, K. 2014. Quality assessment of mixed fruit squash: physico-chemical analysis, sensory evaluation and storage studies. Journal of the Bangladesh Agricultural University, 12(1): 195-201.

Kesava Reddy, C.; Sivapriya, T. V. S.; Arun Kumar, U. and Ramalingam, C. 2016. Optimization of Food Acidulant to Enhance the Organoleptic Property in Fruit Jellies. Journal of Food Processing \& Technology, 7:11.
Kushala, G.; Sreenivas, K. N. and Siddappa, R. 2012. Product development acceptability and cost effectiveness of jack fruit jam blended with avocado and kokum. Food science research journal, 3(1): 78-80.

Patil M. M.; Kalse, S. B. and Sawant, A. A. 2013. Preparation of guava jam blended with sapota. Agricultural Engineering International: CIGR Journal., 15(1): 167-172.

Pingale, S. A. and Dabhade, V. R. 2015. Development and Sensory Attributes of the Pickle made from Bitter Gourd and Bottle Gourd. International Journal of Science and Research (IJSR). 4(10): 1787-1790.

Razzaque, M. A. 2007. “Khaddo prokrijatkoron”. Text book division, Bangla academi, Dhaka, Bangladesh. pp. 174-177.

Reddy, H. 2004. Development of value added products from aonla (Emblica officinalis L.). M.Sc. Thesis, University of Agricultural Sciences, Bengaluru Karnataka (India).

Singh, I. S. and S. Kumar. 1995. Studies on processing of aonla products. Prog. Hort., 27(1-2): 39-47.

Singh, J. and Chandra, S. 2012. Preparation and evaluation of guava-carrot jelly. International Journal of Food and Fermentation Technology, 2(2): 197-200.

Tilak, B. 1995. Ghare Karo Shilpo Garo. West Bengal State Book Board, Calcutta. India. pp. 1-167.

Yusof, S. and Vengrasalam, K. 1994. Effect of Processing Techniques on the Quality and Acceptability of Young Carambola (Averrhoa carambola) Fruit Pickle. Pertanika Journal of Tropical Agricultural Science, 17(3): 201-208. 